\title{
Growth Performance and Digestibility of Starter Broiler Chicks Fed Diets Containing Different Duration of Fermented Baobab (Adansonia digitata) Seed Meal
}

\author{
I. Y. Gyang, F. B. P. Abang, and D. T. Shaahu
}

\section{ABSTRACT}

\begin{abstract}
A nutrient retention and growth performance study were conducted with broiler chicks to evaluate the effect of different duration of fermented baobab seed meal (FBSM). Fermented baobab (Adansonia digitata) seeds were ground and incorporated in the diets at $12 \%$ dietary level. Diet 1 (control diet) had no BSM. Diet 2 had unfermented BSM. Diets 3, 4 and 5 had baobab seed meal (BSM) fermented for $48 \mathrm{~h}, 72 \mathrm{~h}$ and $96 \mathrm{~h}$, respectively. Two hundred and forty (240) Arbor Acre chicks at one-week old were weighed and distributed to these dietary treatments. The five (5) treatments were replicated four (4) times in a completely randomized design, with 12 birds per replicate ( 48 per treatment). The diets did not significantly $(p>0.05)$ influenced Feed intake, final body weight, feed conversion ratio and protein intake across treatments. The body weight gain and protein efficiency ratio of the chicks fed $96 \mathrm{~h}$ fermented BSM were not significantly (p>0.05) different with those fed control diet but were significantly $(p<0.05)$ higher than chicks of other treatment groups. Starter broiler chicks fed T4 had significantly $(\mathbf{p}<0.05)$ higher nutrient digestibility parameters across treatments, except for $\mathrm{EE}$ and $\mathrm{CF}$ that were highly digested by chicks fed T3 and $\mathrm{T} 1$ respectively. In conclusion the performance of broiler chicks fed $96 \mathrm{~h}$ FBSM competed favorably with those fed control diet, whereas, chicks placed on $72 \mathrm{~h}$ FBSM recorded better result of nutrient digestibility.
\end{abstract}

Keywords: Broiler Chicks, Fermented Baobab Seeds, Growth Performance, and Nutrient Digestibility.
Submitted : June 24, 2021

Published : August 06, 2021

ISSN: $2684-1827$

DOI: $10.24018 /$ ejfood.2021.3.4.332

I. Y. Gyang *

Department of Animal Health and Production Technology, Plateau State College of Agriculture, Garkawa, Nigeria.

(e-mail:mapakiliya123@gmail.com) F. B. P. Abang

Department of Animal Production, Federal University Agriculture, Makurdi, Nigeria.

(e-mail:abang.favour2@gmail.com) D. T. Shaahu

Department of Animal Production, Federal University of Agriculture, Makurdi, Nigeria.

(e-mail: dtshaatu@gmail.com)

*Corresponding Author

\section{INTRODUCTION}

Poultry farmers in Nigeria for the past decades have been using the conventional feedstuffs (soybean meal and groundnut cake) in producing poultry feeds. Unfortunately, these feed ingredients have become scarce, oftentimes unavailable, and very expensive [1]. Research emphasis by animal nutritionists is now on the potentials of lesser-known, ignored and underexploited trees and shrubs that are native to Africa as protein and energy sources. Baobab (Adansonia digitata L.) belongs to such category [2]. In Nigeria it grows widely in the northern regions [4], [5]. Baobab seeds have been found to be rich in protein (20-36\%) and energy (1898$4465 \mathrm{kcal} / \mathrm{kg}$ ) and also provide some necessary fibre, vitamins, minerals and amino acids, particularly, lysine and methionine which are limiting in most cereals [6], [7] and [8]. However, like many nonconventional feedstuffs, baobab seeds have been found to contain some anti-nutritional factors such as tannins, oxalates, phytate, and saponin which limits it digestion, absorption, and utilization by broiler chickens.

The seeds therefore require some form of processing such as soaking, boiling, toasting and fermentation so as to facilitate the utilization of its nutrients by broiler birds [1], [9]. References [10], [11] have successfully used differently processed baobab seeds at $10 \%$ inclusion levels. Reference [12] recommended $15 \%$ for growing rabbits. Reference [13] had reported that dietary levels of toasted baobab seed meal beyond $22.5 \%$ resulted in a decline in weight gain and feed to gain ratio of broiler chickens.

Reference [14] stated that the identification and removal of factors that inhibit nutrient utilization are necessary for successful poultry production. Among potential factors reducing nutrient bioavailability are anti-nutritional factors. Reference [15] had reported that feed ingested by broiler birds is not entirely digested and absorbed in the body system, but some are undigested and found their way out as animal feace. Digestibility is therefore an index of the disappearance of food in the intestine, but not of the efficiency of use of food by animal metabolism. However, food can be highly digestible without providing enough nutrients to make up needs of animal [15]. Diets provided to chickens must undergoes series of physio-chemical actions prior absorption and assimilation, [16], [15].

Feed digestibility indicate how much the body uses feeds and nutrients, this depends on animal species, strain, and age. Not all feed fractions are absorbable, some are voided and found their way out as faeces [15]. In vivo digestibility made it possible to better understand the percentage of nutrient utilization (organic matter, amino acid, fat and metabolizable 
energy) absorption in the digestive tract and which constitute the fraction that can be used for metabolism [15]. The objective of this study was to evaluate the effect of duration of fermentation of baobab seed on growth performance and nutrient digestibility by broiler chicks.

\section{MATERIALS AND METHODS}

\section{A. Experimental Site}

The experiment was conducted at Dan-Agro Poultry Farm, a subsidiary of Dan-Agro Feeds, Zawan, Jos South Local Government Area of Plateau State, Nigeria. The study was carried from $6^{\text {th }}$ December $2018-31^{\text {st }}$ January 2019. Zawan is located on a geographical coordinates of latitude $9^{\circ} 48^{\prime} 00^{\prime \prime}$ North and longitude $8^{\circ} 52^{\prime} 00^{\prime \prime}$ East. With an altitude of about 1829 meters above sea level. Has an annual rainfall of 1300$1500 \mathrm{~mm}$ (55 inches) while the dry season starts from October - March. Temperature range between $12.9-13^{\circ} \mathrm{C}$. An average relative humidity of $65 \%$ [17].

\section{B. Source of Baobab Seeds Experimental Site}

Baobab seeds used for the experiment were purchased from Lur village in Kabwir District of Kanke Local Government Area of Plateau State, Nigeria.

\section{Processing of Baobab Seed Meal}

The seeds were washed to remove the pulp on the seed coat, sun dried, then winnowed to remove particles (debris) of fibrous and broken woody pericarp of the dried baobab fruit. The baobab seeds were divided into four (4) equal parts. The first part was left unprocessed; the $2^{\text {nd }}, 3^{\text {rd }}$ and $4^{\text {th }}$ parts were soaked for 24 hours using tap water. The seeds were then drained of the water using a perforated stainless pan for 20 minutes. Each part was then placed and tied in polythene bag and covered in a 300 litre plastic drum (an anaerobic environment) and left to ferment. The $2^{\text {nd }}, 3^{\text {rd }}$ and $4^{\text {th }}$ parts of baobab seeds were left to ferment for $48 \mathrm{~h}, 72 \mathrm{~h}$ and $96 \mathrm{~h}$, respectively. After fermentation the seeds were washed again to remove any fungus or leached anti nutrients. They were sun-dried for 5 days until crisp. Each part was ground in a hammer mill and sieved in $2 \mathrm{~mm} \times 2 \mathrm{~mm}$ plastic mesh sieve and then incorporated into the starter diets.

\section{Experimental Diets}

Diet 1 , the control diet, had no baobab seed meal. It was a conventional diet containing groundnut cake and toasted soybeans as the protein sources. Diet 2 contained raw or unprocessed baobab seed meal. Diets 3, 4 and 5 contained baobab seeds fermented for $48 \mathrm{~h}, 72 \mathrm{~h}$ and $96 \mathrm{~h}$, respectively. The diets were iso-caloric and iso-nitrogenous. Table I showed the gross composition, calculated, and analyzed nutrient content of starter diets. This fell within the recommended range of $22-24 \%$ crude protein and 2900$3000 \mathrm{Kcal} / \mathrm{kg}$ metabolizable energy as reported by [18] for broiler chickens.

\section{E. Design and Management of Experimental Birds}

A total number of 240 day-old Arbor Acre broiler chicks were purchased from ECWA Farm, Jos, Plateau State, Nigeria were used for the experiment. The chicks were placed on commercial diet (supreme broiler starter) for one week to acclimatized and enhance the development of their gastrointestinal tract before introducing them to the experimental diets. On the day of arrival, they were administered multivitamins (Anupco Vitalyte Extra and Antibiotics Doxygen) to combat any stress and infections. At $7^{\text {th }}$ day old they were weighed and randomly allocated to the five (5) dietary treatments replicated four (4) times, in a completely randomized design. Each replicate had twelve (12) chicks with 48 chicks per treatment. All management practices and vaccination programs against Newcastle and infectious Bursal disease were strictly adhered to. Feed and water were administered ad libitum, which lasted for 21days.

\section{F. Performance of Broiler Chicks}

Records of live weight and feed intake were taken weekly, at the beginning of every week a quantity of feed was weighed and allocated to each replicate group; left-over feeds were also weighed at the end of the week and subtracted from the initial feed supplied to obtain feed intake for the week. Weekly weights were taken of the birds in each replicate. The total weight of the birds in each pen was determined by subtracting the initial body weight for the week from the body weight at end of the week. Through these data, feed intake, body weights, weight gain, protein intake and other performance parameters were determined:

1. Feed conversion ratio (FCR) was calculated by dividing the weekly feed intake per bird in grams by weekly body weight gain per bird in grams for each treatment group.

$$
F C R=\frac{\text { Feed intake }(g)}{\text { Body weight gain }(g)}
$$

2. Protein intake $=$ Total feed consumed per bird $(\mathrm{g}) \times \%$ CP of feed.

3. Protein efficiency ratio (PER) was obtained by dividing the weight gain per bird $(\mathrm{g})$ by its protein intake $(\mathrm{g})$ during the experiment.

$$
\text { PER }=\frac{\text { Body weight gain }(g)}{\text { Protein intake }(g)}
$$

4.

Apparent digestibility $=$

$=\frac{\text { Nutrient intake in feed }- \text { Nutrient voided in feces }}{\text { Nutrient intake in feed }} \times 100$

\section{G. Nutrient Digestibility by Broiler Chicks}

At week 3, three (3) birds were taken from each treatment and placed in metabolic cages for collection of feaces (digestibility studies). Fresh excreta were collected in the morning, weighed, and oven dried for a period of four (4) days. The oven-dried excreta were used for analysis and subsequently used for digestibility calculation. Dry matter and nutrient digestibility were calculated according to [19]. 
TABLE I: Gross COMPOSITION (\%) OF BROILER STARTER DiETS CONTAINING FERMENTED BAOBAB SEED MEAL

\begin{tabular}{|c|c|c|c|c|c|}
\hline \multirow{3}{*}{ Ingredient } & \multicolumn{5}{|c|}{ Experimental Diets } \\
\hline & T1 & $\mathrm{T} 2$ & $\mathrm{~T} 3$ & T4 & T5 \\
\hline & Control & $0 \mathrm{~h}$ FBSM & $48 \mathrm{~h}$ FBSMh & 72 h FBSM & $96 \mathrm{~h}(\mathrm{FBSM})$ \\
\hline Maize & 43.36 & 37.99 & 36.21 & 37.58 & 39.73 \\
\hline Soybeans & 25.09 & 18.46 & 20.24 & 18.87 & 16.72 \\
\hline BSM & 0.00 & 12.00 & 12.00 & 12.00 & 12.00 \\
\hline GNC & 21.00 & 21.00 & 21.00 & 21.00 & 21.00 \\
\hline Fish meal & 1.50 & 1.50 & 1.50 & 1.50 & 1.50 \\
\hline Wheat bran & 2.00 & 2.00 & 2.00 & 2.00 & 2.00 \\
\hline Rice offal & 3.00 & 3.00 & 3.00 & 3.00 & 3.00 \\
\hline Bone meal & 2.00 & 2.00 & 2.00 & 2.00 & 2.00 \\
\hline Limestone & 1.00 & 1.00 & 1.00 & 1.00 & 1.00 \\
\hline Common salt & 0.30 & 0.30 & 0.30 & 0.30 & 0.30 \\
\hline Premix & 0.25 & 0.25 & 0.25 & 0.25 & 0.25 \\
\hline Lysine & 0.25 & 0.25 & 0.25 & 0.25 & 0.25 \\
\hline Methinine & 0.25 & 0.25 & 0.25 & 0.25 & 0.25 \\
\hline Total & 100.00 & 100.00 & 100.00 & 100.00 & 100.00 \\
\hline \multicolumn{6}{|c|}{ Calculated nutrients } \\
\hline Crude protein & 24.00 & 24.00 & 24.00 & 24.00 & 24.00 \\
\hline $\mathrm{ME} \mathrm{Kcal/Kg}$ & 2941.94 & 2940.81 & 2937.11 & 2934.43 & 2941.90 \\
\hline Crude fibre & 3.39 & 4.20 & 4.34 & 4.24 & 4.22 \\
\hline Ether extract & 8.52 & 8.41 & 8.81 & 8.36 & 8.29 \\
\hline Calcium & 1.26 & 1.26 & 1.27 & 1.26 & 1.26 \\
\hline Phosphorus & 0.78 & 0.52 & 0.64 & 0.62 & 0.64 \\
\hline Lysine & 1.15 & 1.15 & 1.23 & 1.29 & 1.27 \\
\hline Methionine & 0.36 & 0.36 & 0.38 & 0.36 & 0.39 \\
\hline \multicolumn{6}{|c|}{ Analyzed Nutrients } \\
\hline DM & 94.37 & 94.07 & 93.79 & 94.38 & 94.77 \\
\hline $\mathrm{CP}$ & 23.85 & 24.70 & 24.09 & 24.59 & 24.07 \\
\hline $\mathrm{EE}$ & 5.27 & 5.26 & 7.55 & 6.64 & 6.40 \\
\hline Ash & 9.69 & 10.41 & 10.80 & 11.26 & 10.15 \\
\hline $\mathrm{CF}$ & 3.61 & 4.01 & 3.82 & 4.40 & 4.42 \\
\hline NFE & 57.58 & 55.62 & 53.74 & 53.11 & 54.96 \\
\hline $\mathrm{ME}(\mathrm{kcal} / \mathrm{kg})$ & 3353.94 & 3315.00 & 3411.41 & 3333.74 & 3360.71 \\
\hline $\begin{array}{l}\text { T1 = Control diet, T } \\
\text { T4 = Diet containin } \\
\text { Fermented baobab s } \\
\text { fibre, NFE = Nitrog } \\
\text { Vitamin-mineral pre } \\
\text { Niacin } 12000 \mathrm{mg} \text {; } \\
1000 \mathrm{mg} \text {; Vit-Iron } 1\end{array}$ & $\begin{array}{l}\text { taining unt } \\
\text { rmented b } \\
=\text { Hours o } \\
\text { act, ME = } \\
\text { IX(R)) Wi } \\
\text { id } 2000 \mathrm{~m} \\
\text { nc } 800 \mathrm{mg}\end{array}$ & $\begin{array}{l}\text { baobab seed } \\
\text { d meal, T5 } \\
\text { tion, DM = } \\
\text { zable energy } \\
\text { ger Kg diet: } \\
000 \mathrm{mg} \text {; Vit } \\
400 \mathrm{mg} \text {; Iod }\end{array}$ & $\begin{array}{l}\mathrm{T} 3=\text { Diet cont } \\
\text { containing } 96 \mathrm{~h} \\
\text { atter, } \mathrm{CP}=\mathrm{Cr} \\
=\text { Groundnut } \\
500 \mathrm{IU} \text {; Vit. D3 } \\
000 \mathrm{mg} \text {; Folic a }\end{array}$ & $\begin{array}{l}\text { 48hours ferm } \\
\text { rmented baol } \\
\text { tein, EE = Et } \\
\text { BSM Fermen } \\
\text {; Vit. E12000 } \\
\text { D00 mg; Choli } \\
\text { elenium } 8000\end{array}$ & $\begin{array}{l}\text { aobab seed mea } \\
\text { d meal, FBSM } \\
\text { ract, CF = Crud } \\
\text { obab Seed Mea } \\
\text { it. K3 } 15000 \text { ms } \\
\text { mg; Manganes }\end{array}$ \\
\hline
\end{tabular}

\section{H. Proximate Analysis}

The experimental diets and feaces were analyzed through the official method of the Association of Official Analytical Chemists [20] were used for determination of dry matter, crude fibre, protein and fat content of the samples.

Nitrogen free extract (NFE) was determined by the difference of the sum of all the proximate fraction from $100 \%$.

$$
\mathrm{NFE}=\% \mathrm{DM}-(\% \mathrm{EE}+\% \mathrm{CP}+\% \mathrm{Ash}+\% \mathrm{CF}
$$

The metabolizable energy (ME) of the experimental diets and feaces were calculated according to the formula of [21].

$\mathrm{ME}(\mathrm{kcal} / \mathrm{kg})=37 \times \% \mathrm{CP}+81.1 \times \% \mathrm{EE}+35.5 \times \% \mathrm{NFE}$

where: $\mathrm{DM}=$ Dry matter, $\mathrm{CP}=$ Crude protein, $\mathrm{CF}=$ Crude fibre, $\mathrm{EE}=$ Ether extract and NFE = Nitrogen free extract.

\section{Statistical Analysis}

All data obtained were subjected to analysis of variance procedure of [22] version 22. Means were separated using Duncan's Multiple Range Test of the same package.

\section{RESULTS}

\section{A. Growth Performance of Starter Broiler Chicks}

Data on growth performance of broiler chicks from one (1) week to four (4) weeks of age is presented in Table II. The initial weight of one (1) week old chicks ranged from $103.91 \mathrm{~g}$ to $109.69 \mathrm{~g}$. There were no significant $(\mathrm{p}>0.05)$ differences in the feed intake (FI), final weight (FW), feed conversion ratio (FCR) of broiler chicks across all treatment groups. The weight gain (WG) of $468.10 \mathrm{~g} / \mathrm{bird}$ for chicks fed T5 were not significantly $(\mathrm{p}<0.05)$ different from ( $578.38 \mathrm{~g} / \mathrm{bird})$ for chicks fed $\mathrm{T} 1$, but were significantly $(\mathrm{p}<0.05)$ higher than $(407.73 \mathrm{~g}, 377.50 \mathrm{~g}$ and $376.84 \mathrm{~g} / \mathrm{bird})$ for chicks fed T2, T3 and T4 respectively. The protein efficiency ratio (PER) of 1.48 and 1.59 for chicks fed T2 and T5 respectively were not significantly $(\mathrm{p}>0.05)$ different from 1.99 for chicks fed control diet but were statistically similar to 1.22 and 1.35 for chicks fed $\mathrm{T} 3$ and $\mathrm{T} 4$.

\section{B. Dry Matter and Nutrient Digestibility by Starter broiler chicks}

The result on dry matter and nutrient digestibility by starter broiler chicks is presented in Table III. I observed that DM digestibility ranged from 45.57 to $75.52 \%, \mathrm{CP}$ (59.28 to $82.65 \%), \mathrm{CF}$ (42.74 to $65.41 \%), \mathrm{EE}(67.03$ to $87.19 \%)$ and NFE (37.25 to $70.34 \%)$. The quantity of digestible DM and $\mathrm{CP}$ were significantly $(\mathrm{p}<0.05)$ higher in T4. Chicks fed T5 
had similar quantity of digestible DM and CP with T4. However, chicks fed T2 poorly digested the DM in feed. The result of EE showed that fat and oil in the diets were highly digestible by the birds. I observed that $\mathrm{CF}$ was not adequately digested by the birds in T2, T3 and T5. Results of NFE for
T1, T3, T4 and T5 revealed that the birds were able to digest the carbohydrate component of the feed by chicks except chicks fed T2 $(37.25 \%)$. Birds placed on T1 were able to digest NFE at $(61.72 \%)$.

TABLE II: PERformance of StARTer Broiler Chicks Fed Diets CONTAining Baobab Seed MeAL

\begin{tabular}{|c|c|c|c|c|c|c|}
\hline \multirow{3}{*}{ Parameters } & \multicolumn{5}{|c|}{ Experimental Diets } & \multirow{3}{*}{ SEM } \\
\hline & $\mathrm{T} 1$ & $\mathrm{~T} 2$ & T3 & $\mathrm{T} 4$ & T5 & \\
\hline & $\mathrm{CD}$ & $0 \mathrm{~h}$ FBSM & 48 h FBSM & $72 \mathrm{~h} \mathrm{FBSM}$ & 96 h FBSM & \\
\hline IW (g/bird) & 103.91 & 109.69 & 107.92 & 106.59 & 103.91 & $0.01^{\mathrm{ns}}$ \\
\hline FI (g/bird) & 1194.90 & 1069.53 & 1148.07 & 1056.30 & 1121.82 & $0.12^{\mathrm{ns}}$ \\
\hline FW (g/bird) & 682.29 & 517.42 & 485.42 & 483.43 & 572.01 & $0.06^{\mathrm{ns}}$ \\
\hline WG (g/bird) & $578.38^{\mathrm{a}}$ & $407.73^{\mathrm{b}}$ & $377.50^{\mathrm{b}}$ & $376.84^{\mathrm{b}}$ & $468.10^{\mathrm{ab}}$ & $0.05^{*}$ \\
\hline FCR & 2.07 & 2.62 & 3.04 & 2.80 & 2.40 & $0.30^{\mathrm{ns}}$ \\
\hline PER & $1.99^{\mathrm{a}}$ & $1.48^{\mathrm{ab}}$ & $1.22^{\mathrm{b}}$ & $1.35^{\mathrm{b}}$ & $1.59^{\mathrm{ab}}$ & $0.09^{*}$ \\
\hline
\end{tabular}

a,b,c,d Means within each row with different superscripts are significantly $(\mathrm{p}<0.05), *(\mathrm{p}<0.05)$, ns Not significantly different $(\mathrm{p}>0.05)$, SEM $=$ Standard error of means, $\mathrm{CD}=$ Control diet $\mathrm{T} 1=$ Control diet without baobab seed meal, T2 = Diet containing nfermented baobab seed, T3 = Diet containing baobab seeds obtained after $48 \mathrm{~h}$ fermentation. T4 = Diet containing baobab seeds obtained after $72 \mathrm{~h}$ fermentation, T5 = Diet containing baobab seeds obtained after $96 \mathrm{~h}$ fermentation, FBSM = Fermented baobab seed meal, h = Hours, FI = Feed intake, IW = Initial body weight, FW = Final body weight, WG = Weight gain, $\mathrm{FCR}=$ Feed conversion ratio, $\mathrm{PER}=$ Protein efficiency ratio, $\mathrm{SEM}=$ Standard error of means, $\mathrm{P}=$ Percentage level of significance.

TABLE III: Nutrient Digestibility By STARTER BROILER CHICKS FED FERMENTED BAOBAB SEED MEALS

\begin{tabular}{|c|c|c|c|c|c|c|}
\hline \multirow{3}{*}{ Parameters (\%) } & \multicolumn{5}{|c|}{ Experimental Diets } & \multirow{3}{*}{ SEM } \\
\hline & $\mathrm{T} 1$ & $\mathrm{~T} 2$ & T3 & $\mathrm{T} 4$ & T5 & \\
\hline & $\mathrm{CD}$ & $0 \mathrm{~h}$ FBSM & 48 h FBSM & 72 h FBSM & 96 h FBSM & \\
\hline $\mathrm{DM}$ & $65.20^{\mathrm{b}}$ & $45.57^{\mathrm{c}}$ & $67.14^{\mathrm{b}}$ & $75.52^{\mathrm{a}}$ & $70.78^{\mathrm{ab}}$ & $2.56^{*}$ \\
\hline $\mathrm{CP}$ & $73.43^{b}$ & $59.28^{\mathrm{c}}$ & $74.42^{\mathrm{b}}$ & $82.65^{\mathrm{a}}$ & $76.64^{\mathrm{ab}}$ & $1.98^{*}$ \\
\hline $\mathrm{EE}$ & $82.36^{\mathrm{ab}}$ & $67.03^{\mathrm{c}}$ & $87.19^{\mathrm{a}}$ & $86.65^{\mathrm{a}}$ & $80.13^{\mathrm{b}}$ & $1.85^{*}$ \\
\hline $\mathrm{CF}$ & $65.41^{\mathrm{a}}$ & $42.74^{\mathrm{b}}$ & $48.90^{\mathrm{b}}$ & $54.60^{\mathrm{ab}}$ & $47.92^{\mathrm{b}}$ & $2.36^{*}$ \\
\hline NFE & $61.72^{\mathrm{a}}$ & $37.25^{\mathrm{b}}$ & $62.40^{\mathrm{a}}$ & $70.34^{\mathrm{a}}$ & $67.43^{\mathrm{a}}$ & $2.95^{*}$ \\
\hline
\end{tabular}

a,b,c, Means within each row with different superscripts are significantly $(\mathrm{p}<0.05),{ }^{*}(\mathrm{p}<0.05), \mathrm{SEM}=\mathrm{Standard}$ error of means, $\mathrm{CD}=\mathrm{Control}$ diet $\mathrm{T} 1=\mathrm{C}$. diet without baobab seed meal, T2 $=$ Diet containing unfermented baobab seed, T3 = Diet containing baobab seeds obtained after $48 \mathrm{~h}$ fermentation. T4 = Diet containing baobab seeds obtained after 72h fermentation, T5 = Diet containing baobab seeds obtained after 96h fermentation, FBSM = Fermented baobab seed meal, $\mathrm{h}=$ Hours, $\mathrm{DM}=$ Dry matter, $\mathrm{EE}=$ Ether extracts, $\mathrm{CF}=$ Crude fibre, NFE = Nitrogen free extract.

\section{DISCUSSION}

\section{A. Growth Performance of Starter Broiler Chicks}

The performance of starter broiler chicks fed diets containing fermented BSM are presented in Table II. Initial weight (IW), feed intake (FI), final weight (FW) and feed conversion ratio (FCR) showed no significant $(p>0.05)$ difference across treatments. This result agrees with the findings of [23], [24] who reported no significant $(p>0.05)$ difference in IW, FI, FW and FCR of starter broiler chicks fed differently processed roselle and baobab seed meal respectively. This study is contrary to the findings of [25], [26] who reportedly observed significant $(\mathrm{p}<0.05)$ difference in FI, FW and FCR of broiler chicks fed diets containing Roselle seeds fermented at varying durations and Baobab seed meal cake fed beyond $10 \%$ level of inclusion respectively. However, the variations may occur due to differences in grain legumes, seed processing and levels of inclusion respectively.

Weight gain of broiler chicks fed T5 is similar with those fed $\mathrm{T} 1$ and is significantly $(\mathrm{p}<0.05)$ higher than those fed $\mathrm{T} 2$, T3 and T4. This study agrees with findings of [27] who reported that body weight gain of broiler chicks fed locust bean seed meal fermented for $96 \mathrm{~h}$ and beyond were similar to chicks fed control diet. This revealed that a linear increase in fermentation period could enriched some unidentified growth factors in the starter test diet that stimulated growth of specific tissues.

Protein efficiency ratio (PER) in this study followed a similar pattern of levels of significance as body weight gain. The PER of chicks fed T2 and T5 were similar to the value for those fed $\mathrm{T} 1$ but were significantly $(\mathrm{p}<0.05)$ higher than those fed T3 and T4. This study showed that protein was efficiently utilized by broiler chicks fed $\mathrm{T} 5$ similar to those fed T1. This result agrees with the findings of [28] who reported that the birds with the highest protein efficiency ratio (PER) were those fed fermented kidney bean diet. This study also corroborated the findings of [29] who reported that the higher protein level obtained for 6 days fermentation of BSM was due to hydrolysis of complex compounds that chelate protein. This makes amino acids readily available and efficiently utilized for body weight gain by broiler chicks. This study revealed that broiler chicks fed fermented BSM at $12 \%$ level of inclusion can produce broiler chicks with similar performance as those fed the control diet.

\section{B. Dry Matter and Nutrient Digestibility by Starter Chicks}

The dry matter and nutrient digestibility of broiler chicks fed BSM are presented in Table IV. Inclusion of unfermented BSM in the starter diet significant $(\mathrm{p}<0.01)$ reduced broiler chick's digestibility of dry matter and all proximate fractions than other treatment groups. The study conformed with the observations of [30], [31] who reported a depressed dry matter and nutrients digestibility of broiler chicks fed raw pigeon pea meal and raw tropical sickle-pod seed meal (Senna obtusifolia) than other treatment groups respectively. Consequently, this poor nutrient digestibility could be attributed to the lack of seed processing, which had been reported to content anti-nutritional factors (tannin, oxalate, phytate, saponin and $\mathrm{HCN}$ ), that form less digestible complex compounds with protein, mineral, vitamins and endogenous enzymes [32]. 
The dietary inclusion of fermented BSM on dry matter and nutrient digestibility has no definite pattern (parabolic). However, when digestibility reaching a pick at $72 \mathrm{~h}$ of fermentation of dietary BSM, it tends to decrease at $92 \mathrm{~h}$ fermentation. The result showed that broiler chicks fed $72 \mathrm{~h}$ FBSM consistently recorded the highest apparent nutrient digestibility value among all other treatment groups, except for $\mathrm{CF}$ and $\mathrm{EE}$ that showed inferiority over $\mathrm{T} 1$ and $\mathrm{T} 3$, respectively.

The low crude fibre digestibility by broiler starter chicks fed FBSM was similar to those fed unfermented BSM diet. This study disagrees with the observations of [33] who reported that chicks fed $\mathrm{T} 1$ consistently recorded the highest apparent nutrient digestibility value than those fed $72 \mathrm{~h}$ fermented castor seed meal diets. This study is also not in line with the findings of [34] who reported that diets containing 8 to $12 \% \mathrm{CF}$ levels at 2800 and $3000 \mathrm{kcal} / \mathrm{kg}$ (ME) without enzyme inclusion resulted in positive growth response. Hence, 3-5 \% CF level is generally recommended for broiler chickens [35], [36]. Variations could be attributed to differences in plant species and processing methods.

The low fibre digestion by broiler chicks in this study could be attributed to the under-development of the gastro-intestinal tract, high crude fibre content of BSM and presence of antinutritional factors. Reference [37] reported that high CF in poultry diets decreases the surface area, width and height of intestinal villi that are associated with nutrient digestion and absorption. Furthermore, indigestible cellulose and hemicellulose of crude fibre (Oligosaccharide) contain molecules of xylose, galactose, and mannose link by $\beta$ glycoside bond all of which are monosaccharide that would have enhanced carbohydrate digestibility [38].

Also, fermentation of grain legume brings about the breakdown of certain constituent, reduction of antinutritional factors, the released of vitamins and minerals thereby improving performance [39], [40]. However, the expression of superior dry matter and nutrient digestibility of broiler chicks fed FBSM in this study had resulted to an improved performance of starter broiler chicks similar to chicks fed control diet.

\section{CONCLUSION}

Baobab seed meal (BSM) Fermented for 96hrs is recommended for inclusion in starter broiler's diets since growth performance of chicks in this study competed favorably with those fed control diet despite the fact that broiler chicks fed 72 hours fermented BSM had better result of nutrient digestibility.

\section{ACKNOWLEDGMENT}

The authors remain grateful to the Managing Director; $\mathrm{Mr}$. Danladi John and the entire Staff of Dan - Agro Farms, a subsidiary of Dan - Agro Products for the provision of space and facilities to conduct this study. I am highly indebted to Prof. S.N. Carew for his supervision and constructive criticism, I say thank you.

\section{REFERENCES}

[1] F.E. Sola-Ojo, K.D. Adeyemi, A.A. Toye, S.A. Bolu, T.R. Fayeye, A.A. Annongu, S.O. Garba and R.O. Karim, "Performance, carcass profile and oxidative stability of broiler chickens fed processed baobab seed meal." Bulletin of Environment Pharmacology and Life Scienves. 2, 94-99, 2013.

[2] L.C. Igboeli, E.O.H. Addy and L.C. Salami, "Effects of some processing techniques on the anti-nutrient contents of baobab seed (Adansonia digitata)." Bioresource Technology, (Elsevier Science Limited), 59: 29-31, 1997.

[3] K.O. Yusuf, A.M. Bamgbose, A.O. Oso, A.O. Fafiolu, A.O. Oni, "Nutritional evaluation of baobab (Adansonia digitata) seed meal with rats." ASSET series A, 8: 226-231, 2008.

[4] G.E Wickens, "The use of the baobab (Adansonia digitata L.) in Africa.” In: le Houerou, H. N. (ed.). Browse in Africa: The current state of knowledge. ILCA, Addis Ababa, Ethiopia, 1980.

[5] FAO, "Traditional food plants." Food and nutrition paper, 42. Food and Agriculture Organization (FAO/UN), Rome. Italy, 1988.

[6] R.H. Glew, D.J. Vander-Jagt, C. Lockett, L.E. Grivetti and G.C. Smith, "Amino acid, fatty acid and mineral composition of 24 indigenous plants of Burkina Faso." Journal of Food Composition and Analysis, 10:205-217, 1997.

[7] S.S. Murray, M.J. Schoeninger, H.T. Bunn, T.R., Pickering, A.M. Judith, "Nutritional composition of some wild plant foods and honey used by hadza foragers of Tanzania." Journal of Food Composition and Analysis, 13: 1-11, 2001.

[8] J. Chimvuramahwe, J.P. Musara, L.C. Mujuru, T. Gadzirayi, W. Nyakudya, "Effect of feeding graded levels of Adansonia digitata (baobab) seed cake on the performance of broilers." Journal of Animal and Plant Sciences, 11: 1442-1449, 2011.

[9] C. Ikemefuna, Obizoba and N.A. Ameachi, "The effect of processing methods on the chemical composition of baobab (Adansonia digitata. L) pulp and seed." Journal of Ecology of Food and Nutrition, 29(3): 199-205, 2010.

[10] L.A. Saulawa, A.I. Yaradua, and L. Shuaibu, "Effect of Different Processing Methods on Proximate, Mineral and Anti Nutritional Factors Content of Baobab (Adansonia digitata) Seeds." Pakistan Journal of Nutrition, 13 (6): 314-318, 2014.

[11] L.Y. Guluwa, P.D Wumnokol, I. Ajiji, S.T. Magaji, J.I. Alokoson, "Effect of Inclusion of Various levels of Toasted Baobab Seed Meal in the diets of Broilers Chickens on their Growth Performance." Institute of Professional Agriculturists of Nigeria. 20th Annual International Conference Book of Conference Proceedings, pp. 30-37, 2015.

[12] I.O. Oladunjoye, M. Akinlade and Z. Lawal, "Performance, digestibility, carcass and blood profile of grower rabbits fed baobab (Adansonia digitata) pulp and seed meal." Indian Journal of Fundamental and Applied Life Sciences, 4(2): 234-240, 2014.

[13] P.J. Damang, "Performance of finisher broiler chickens fed diets containing graded levels of baobab seed meal." Proceedings of National Scientific Conference. $2^{\text {nd }}$ National Conference: Academic Staff Union Colleges of Agriculture, Garkawa, pp.145-149, 2016.

[14] A.F. Agboola, M.O. Awoyemi, U.O. Inyang and S.M. Ogunbode, "Growth response and nutrient digestibility of broiler chickens fed wheat-based diets supplemented with anexogenous enzyme." International Journal of Agricultural and Bioscience, 3(2): 95-101, 2014. www.ijagbio.com

[15] T.S.G. Atchade, M.F. Houndonougbo, M.A.A.C. Chrysostome and A.G. Mensah, "A review Digestibility of feeds in broiler chicken in Africa." International Journal of Biological and Chemical Sciences, 13(2): 1127-1139, 2019.

[16] D. Sauvant, "Principes générauxde l'alimentation animale." INRA: Paris-Grignon, p. 147, 2004.

[17] Jos South-Wikipedia, 'Retrieved from'https://en.m.wikipedia.org>wiki>jos-s..., 2017.

[18] A.O. Aduku, "Tropical Feeding stuff Analysis Table." Department of Animal Science, Ahmadu Bello University, Zaria, 2005. 'Retrieved from' https://www.scirp.org.

[19] P. McDonald, R.A. Edwards and J.F.H. Greenhalgh, "Animal Nutrition." $5^{\text {th }}$ Edition, Longman Group Publications, London, pp. 488, 1995.

[20] A.O.A.C. "Official Method of Analysis of the AOAC, W. Horwitz Editor." (18 ${ }^{\text {th }}$ ed). USA Washington D.C. 132 pp, 2006.

[21] U. Pauzenga, "Feeding parent stock. Zootech characteristics of weaning rabbits fed graded levels." International, 34: 22-25, 1985.

[22] SPSS, "Statistical package for social student, version 22." 'Retrieved from' http://www-01.ibm.com August 26, 2013.

[23] I.D. Kwari, A.O. Raji, J.U. Igwebuike and A. Kibon, "Response of growing cockerels to diets containing differently processed Rossel 
(Hibiscus sabdariffa) seed meal." International Journal of Science and Nature, 1(2): 183-190, 2010.

[24] H. Abdulazeez, U. Mohammed, M.A.A. Jiddah, "Performance and economic parameters of broiler chickens fed baobab (Adansonia digitata $L$.) seed meal as replacement for soyabean meal in semi-arid zone of Nigeria." GJBAHS, 8: 8, 2019.

[25] A.O. Angbulu, "Performance of broiler chickens fed diets containing roselle (Hibiscus sabdariffa $L$.) seeds fermented at varying durations with or without enzyme supplementation." A dissertation submitted to school of postgraduate studies, Ahmadu Bello University, Zaria in partial fulfilment of the requirements for the award of Master Degree in Animal Science, pp. 77-87, 2017.

[26] P. Chisoro, T. T. Nkukwana J. F. Mupangwa and T. P. Mabusela, "Feed intake, growth performance and carcass traits of broilers fed diets with various inclusion levels of baobab seed oilcake". South African Journal of Animal Science, 48(2): 284-294, 2018.

[27] C.O. Obun, "Performance, digestibility and carcass and organ weights of finisher broiler chicks fed graded levels of fermented locust bean (Parkia biglobosa) seed meal." Asian Journal of Poultry Science, 2(1): $17-23,2008$.

[28] P.J. Damang, C.D. Tuleun, O.I.A. Oluremi, and S.N. Carew, "Evaluation of raw and processed kidney bean (Phaseolus vulgaris L.) seed for mono-gastric animal feed production." Journal of Animal Production Research, 29(1): 301-311, 2017.

[29] I.C. Obizoba and N.A. Ameachi, "The effect of processing methods on the chemical composition of baobab (Adansonia digitate L.) pulp and seed." Journal of Ecology of Food and Nutrition, 29(3): 199-205, 2010.

[30] K.U. Amaefule, U.A. Ukpanah and A.E. Ibok, "Performance of starter broilers fed raw pigeonpea (Cajanus cajan L.) seed meal diets supplemented with lysine and or methionine." International Journal of Poultry Science, 10: 205-211, 2011.

[31] C. Augustine, I.K. Dankasa, I.J. Uchei, A.S. Bala and D.S. Siaka, "Nutrient digestibility and growth performance of broiler chickens fed processed tropical sickle pod (Senna obtusifolia L.) Seed meal baseddiets." Journal of Agricultural Sciences, 62(4): 37-384, 2017.

[32] M.O. Aremu, O. Olonisakin, D.A. Bako and P.C. Madu, "Compositional studies and physicochemical characteristics of cashew nut (Anarcedium occidentale) flour." Pakistan Journal of Nutrition, 5(4): 328-333, 2006.

[33] G.G. Mustapha, J.U. Igwebuike, I.D. Kwari, S.B. Adamu and Y. Abba "The effect of replacement levels of boiled and fermented castor seed (Ricinus cummunis) meal on the productive performance, nutrient digestibility, carcass characteristics and cost effectiveness in broilers." International Journal Science Nature, 6(4): 675-682, 2015.

[34] R.I. Salami and A.A. Odunsi, "Effect of varying dietary fibre and energy levels in multi-fibre source-based diets on growth performance of broiler finisher chickens." Nigerian Journal of Animal Science, 19: 72-82, 2017.

[35] NRC. "Nutrient Requirement of Poultry." (9th Rev. ed)., National Academy Press, Washington, DC., USA., ISBN - 13: 978-0-30904892-7, 176 pp, 1994.

[36] A.O. Aduku, "Feed ingredient and diet composition tables for the tropics." Davcon computers and business bureau, Kaduna, Nigeria, pp. 25-27, 2004

[37] R. Kalmendal, K. Elwinger, L. Holm and R. Tauson, "High-fibre sunflower cake affects small intestinal digestion and health in broiler chickens." Journal of British Poultry Science, 52: 86-96, 2011.

[38] A. Drażbo, D. Mikulski, J. Jankowski and Z. Zduńczyk, "The effect of diets containing raw and fermented faba beans (Vicia faba L.) on gut functioning and growth performance in young turkeys." Journal of Animal and Feed Sciences, 27: 65-73, 2018.

[39] C.D. Tuleun, A.Y. Adenkola and K.T. Orayaga, "Naturally fermented Mucuna seed meal base diets: Effect on performance and carcass characteristics of broiler chickens." Research Journal of Poultry Sciences, 4: 50-55, 2011.

[40] O. Oladapo, F. Chrishanthi, M. Ram, L. Xiuhua and S. Yasmina, "Solid-state fermented plant protein source in the diets of broiler chickens." A Review. Journal Animal Nutrition, 5(4): 319 - 4. 